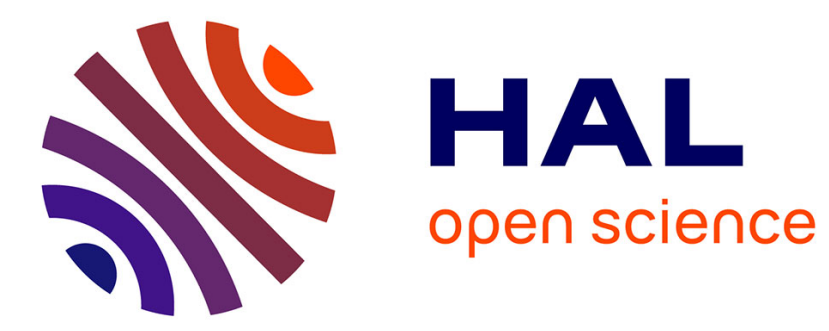

\title{
The never-ending story of cucurbits and viruses
}

Cecile Desbiez

\section{To cite this version:}

Cecile Desbiez. The never-ending story of cucurbits and viruses. Acta Horticulturae, 2020, 1294, pp.173-192. 10.17660/ActaHortic.2020.1294.23 . hal-03019048

\section{HAL Id: hal-03019048 \\ https://hal.inrae.fr/hal-03019048}

Submitted on 10 Feb 2022

HAL is a multi-disciplinary open access archive for the deposit and dissemination of scientific research documents, whether they are published or not. The documents may come from teaching and research institutions in France or abroad, or from public or private research centers.
L'archive ouverte pluridisciplinaire HAL, est destinée au dépôt et à la diffusion de documents scientifiques de niveau recherche, publiés ou non, émanant des établissements d'enseignement et de recherche français ou étrangers, des laboratoires publics ou privés. 


\title{
The never-ending story of cucurbits and viruses
}

\author{
C. Desbiez \\ INRA, UR407 Pathologie Vegetale, 84143 Montfavet Cedex, France
}

\begin{abstract}
Cucurbits are widely grown worldwide in diverse agroecosystems. Viruses represent one of the major threats for cucurbit production. More than 90 viruses have been described infecting cucurbits in natural conditions. Their prevalence and agronomic impact are highly contrasted, and the major problems at the worldwide level are related to circa 10 virus species, both « classic » i.e known for decades- or recently emerged on a large scale. Among the « old » mosaic-inducing viruses, aphid-transmitted viruses (potyviruses, cucumber mosaic virus) remain agronomically important, particularly in temperate climates. Despite their long-term prevalence and apparent stability, introductions of new strains have been observed in several countries in the last years, probably via commercial exchanges of plant material. Some of these introduced strains have rapidly replaced pre-existing virus populations, sometimes resulting in an increased economic impact. In Mediterranean and tropical climates, as well as in heated greenhouses in temperate regions, whitefly-transmitted viruses (begomoviruses, ipomoviruses, criniviruses) now constitute major problems. Their rapid emergence can be explained by the combination of changes in climate and cultural practices that favour their natural vectors, and the increased exchanges of plant material that made possible their long-distance spread. Thrips-transmitted viruses are present in Asia and Latin America and can be locally very damaging. Viruses transmitted by seeds or by contact are also easily disseminated worldwide and represent important constraints for exchanges of plants or genetic material. Accurate and regular reevaluation of the complex viral pathosystem infecting cucurbits in different countries, adaptation of cultural practices and development of resistant cultivars contribute to the continuous arm race against the introductions and local evolution of virus populations.
\end{abstract}

Keywords: epidemiology, viral disease, emergence, transmission, evolution, control, emergence

\section{INTRODUCTION}

Cucurbits are among the most important vegetable crops worldwide. Among the circa 800 species described, the major crops are melon (Cucumis melo), cucumber (C. sativus), watermelon (Citrullus lanatus) and different squashes (Cucurbita pepo, C. moschata, C. maxima). Other cucurbits (bitter gourd, chayote) are also grown in some parts of the world (http://www.fao.org/faostat/). Mature or immature cucurbit fruits are used for human or animal consumption. Seeds are used as snack or for oil production. Some cucurbits are grown for ornamental use (colocynths), as sponges (Luffa acutangula) or as containers or music instruments (Lecoq et al., 1998; Romay et al., 2014).

Whereas many wild cucurbits are perennial, cultivated ones are mostly annual. A great variety of types and cultivars are grown in relation to local conditions and consumer's tastes. Cucurbits are grown in very diverse agroecosystems, from traditional rain fed or irrigated gardens to sophisticated soilless glasshouses.

Cucurbits production is threatened by several pests and diseases. Insects or nematodes induce direct damages to the crops, and can also transmit viruses. Viruses represent challenging problems as they can impair both the yield and the quality of the crops, and no curative methods are available. Viruses rarely cause plant death, but they can induce different symptoms belonging mostly to three categories:

-mosaics, i.e. patterns of discoloration on the leaves or fruits, often associated with deformations and size reduction. Fruit quality can be altered with low sugar content, and sometimes marbling and hardening of the flesh 
-necrosis affecting some organs (necrotic spots on leaves or fruits) or the whole plant, sometimes leading to general wilt and death

-yellowing of the older leaves that also become brittle. Fruit production can be reduced but the quality of the fruits is not obviously affected.

Mixed infection of several viruses in a single plant are common and can result in more severe symptoms.

Cucurbit-infecting viruses represent a highly dynamic system. Several novel virus species, and/or viruses that were present on other hosts but are now found to infect cucurbits, are described each year, as well as new locations or new hosts for known viruses. Many of these viruses have a potential or acknowledged agronomic impact. Until recently, descriptions of new viruses included a characterization of their symptomatology, host range, and transmission properties. With the development of high-throughput sequencing, some viruses are known only by their molecular properties without any information on their importance in plants. Completely asymptomatic viruses that could be commensal or even beneficial to plants are thus described, but the risks of their evolving to become deleterious are unknown.

\section{APHID-TRANSMITTED VIRUSES: OLD VIRUSES, NEW STRAINS, PERSISTING PROBLEMS}

Aphids constitute important agronomic problems in themselves. They induce direct damages to crops by their sap-sucking feeding: plant weakening, leaf crispation in response to saliva toxicity and photosynthesis reduction. Their feeding behaviour makes them particularly efficient virus vectors. For some virus genera, virus acquisition and transmission take place during short probing punctures of the aphid stylet in the epidermal cells of the plants (non-persistent transmission). In that case, the transmission is not very specific, many aphid species can transmit a given virus. The virus remains in the stylet of the aphid, its retention lasts only minutes to hours and the aphid remains viruliferous for less than one day. Other virus species are persistently transmitted: the aphid acquires the virus after several hours of feeding in the phloem of an infected plant. The virus transits through the insect gut and the haemolymph, then migrates to the salivary glands where it can be released to a new plant when the aphid feeds on the phloem of another healthy susceptible plant. In that case, the transmission is more specific, only one or a few aphid species can transmit a given virus. The aphid can remain viruliferous all its life (Ng and Perry, 2004).

In cucurbits, viruses from the genera Cucumovirus and Potyvirus are non-persistently aphidtransmitted, whereas viruses from the genus Polerovirus are persistently-transmitted.

\section{Cucumber mosaic virus (CMV)}

Cucumber mosaic virus (CMV, genus Cucumovirus) has small icosahedral particles of circa $29 \mathrm{~nm}$ in diameter. CMV is among the first plant viruses described, more than one century ago. Its genome consists of 3 positive-stranded RNAs, encapsidated separately. CMV has one of the broadest host ranges for a plant virus, it infects more than 1000 species, both dicots and monocots. The symptoms on cucurbits usually consist in mosaics and deformations on leaves and fruits. CMV is efficiently transmitted non-persistently by more than 60 aphid species. Interestingly, CMVinfected plants attract aphids by the emission of volatiles, but aphids perform poorly on infected plants and tend to emigrate quickly. This manipulation of aphid behaviour can increase virus spread (Mauck et al., 2010). CMV is seed-transmitted in some hosts, but seed transmission in cucurbits seems to be rare (Jacquemond, 2012; Lecoq et al., 1998).

Two major subgroups of CMV, namely groups I and II, have been defined based on biological, serological and molecular properties. Strains from group I were also called heat-resistant, contrary to the heat-sensitive group II (Jacquemond, 2012). Within group I, two major subgroups are acknowledged, namely IA and IB. Group IA is widespread throughout the world; group IB was mostly present in Asia until recently. Reassortants, i.e. virus isolates whose RNAs belong to different groups or subgroups, and recombinants -presenting genetic exchanges within one RNAhave been observed (Jacquemond, 2012; Ohshima et al., 2016). Reassortants can present fitness advantages in some hosts and become predominant in local populations (Ben Tamarzizt et al., 2013). Evolutionary analyses suggested that current CMV populations are the descendants of a 
single ancestor existing 1600-2600 years ago but that the population mostly radiated 300-550 years ago, and that reassortant populations were locally confined and less than 250 years old (Ohshima et al., 2016).

\section{Potyviruses}

At least 20 potyviruses infect cucurbits (Table 1). Three of them, zucchini yellow mosaic virus, papaya ringspot virus and watermelon mosaic virus, are particularly important worldwide. Potyviruses have a single-stranded monopartite genome of about $10 \mathrm{~kb}$, encapsidated in filamentous flexuous particles about $700 \mathrm{~nm}$ long. Viruses in the family Potyviridae, including potyviruses, induce in their infected hosts typical pinwheel-like cytoplasmic inclusions. Potyviruses are non-persistently transmitted by numerous aphid species. They can also be transmitted mechanically by pruning tools or by contact between plants.

\section{Zucchini yellow mosaic virus (ZYMV)}

Zucchini yellow mosaic virus still represents the challenging case of a very successful emerging virus. ZYMV was first observed in a garden in Italy in 1973, and the first severe epidemics took place in France in 1978 (Desbiez and Lecoq, 1997). Within a few years, ZYMV caused severe epidemics in almost all cucurbit-growing areas worldwide (Desbiez and Lecoq, 1997). ZYMV symptoms are usually very severe, and early infections can lead to complete crop losses. ZYMV presents a high biological variability in symptomatology, transmission and ability to overcome resistances. ZYMV has a narrow host range outside cucurbits. In areas where cucurbits are not grown year-round, ZYMV can be maintained in wild annual or perennial cucurbits. The few wild cucurbits present in Europe are not susceptible to ZYMV, and the sources of primary inoculum in epidemics remain a key question. Non-cucurbit hosts including weeds and ornamentals can constitute virus reservoirs (Lecoq et al., 2014) but their prevalence in the vicinity of the crops can be low. In temperate areas, ZYMV epidemics are often irregular, probably in relation to a low probability of primary infections (Lecoq et al., 2009; Lecoq et al., 2014). Studies on ZYMV molecular diversity have revealed three molecular groups, namely A, B, and C without host specificity. Groups B and C are restricted geographically whereas group A contains worldwide isolates including those of the first descriptions in France and Italy. Within group A, 4 to 6 subgroups were defined (Lecoq and Desbiez, 2012). Molecular analyses have allowed in some cases to track the origins of ZYMV strains emerging in new areas. Even in a single location, strain replacement or "switches" have been described (Lecoq et al., 2014), suggesting that distant sources of infection, besides local reservoirs, play an important role in ZYMV epidemics. Natural spread by aphids takes place mostly at a very local scale (Lecoq et al., 2014). Long-distance virus dissemination can happen through infected fruits or plants (Lecoq et al., 2003). Seed transmission of ZYMV has long remained controversial, with estimations ranging from 0 to $18 \%$. Using a sensitive RT-PCR detection method, vertical transmission was observed in Cucurbita pepo subsp. texana at a 1.6\% rate (Simmons et al., 2011). Positive plants were symptomless and had low virus titre, but they could be sources for further horizontal transmission, either by aphids or mechanically (Simmons et al., 2013). Seed transmission may thus have contributed to the rapid worldwide spread of ZYMV, and to the still ongoing frequent exchanges between viral populations.

\section{Watermelon mosaic virus}

Watermelon mosaic virus (WMV) is present worldwide in temperate and Mediterranean areas but is almost absent on cucurbits in tropical areas, without definitive explanation. WMV infects a wide range of cultivated and ornamental hosts as diverse as pea, orchids and ginseng, as well as numerous weeds that can constitute reservoirs. In cucurbits, WMV induces vein banding and mosaic symptoms milder than those of ZYMV, even if some strains cause severe leaf deformations. "Watermelon mosaic disease" has been observed for more than 50 years. Biological and serological studies revealed the presence of two viral entities named WMV-1 and WMV-2. WMV-1 was shown to be a strain of papaya ringspot virus (PRSV, see below) and WMV-2 was renamed WMV. WMV is closely related molecularly to soybean mosaic virus (SMV) but is an interspecific recombinant in the 5' region of the genome between SMV and another legume- 
infecting potyvirus, bean common mosaic virus (Desbiez and Lecoq, 2004). Despite its low biological variability, WMV molecular diversity is high. The first studies based on coat proteincoding regions revealed the presence of three molecular groups showing some correlation with the geographic origin of the isolates: In France and other European countries, Group1 strains present for more than 40 years have been replaced within a decade by Group3 ones probably introduced in the mid-1990s (Desbiez et al., 2009). During the few years of coexistence of the two types of strains, mixed infections were frequent and intraspecific recombinants were detected but they did not emerge in the populations (Desbiez et al., 2011a). The increase of the number of sequences available from worldwide isolates now shows a very complex situation with evidence for numerous long-distance exchanges. WMV has not been described as seed-borne in cucurbits. Long-distance virus spread could be the result of worldwide trade of vegetatively propagated hosts, including orchids or other ornamentals, and/or of cucurbit seedlings, plants or fruits.

\section{Papaya ringspot virus (PRSV) and the "PRSV cluster »}

Papaya ringspot virus (PRSV, formerly WMV-1) induces mosaics and deformations in cucurbit leaves and fruits. After it was considered as a distinct virus from WMV (formerly WMV2 ) it was shown to belong to the same species as a virus previously described on papaya. $P$ (papaya) strains of PRSV infect papaya but have a low infectivity on cucurbits, contrary to W (watermelon) strains that efficiently infect cucurbits but do not infect papaya. Phylogenetic analyses suggest that $\mathrm{P}$ isolates derive from $\mathrm{W}$ isolates, and that the switch took place frequently during the evolution of PRSV. Indeed, a single mutation in the major protease of the virus (NIaPro) is sufficient for the phenotypic change between the $\mathrm{P}$ and $\mathrm{W}$ phenotypes (Chen et al., 2008). Besides PRSV, several viruses closely related biologically, serologically and molecularly constitute a "cluster" of cucurbit-infecting viruses: Moroccan watermelon mosaic virus, Algerian watermelon mosaic virus, zucchini shoestring virus, zucchini tigre mosaic virus, Sudan watermelon mosaic virus, wild melon vein-banding virus, zucchini yellow fleck virus. They are geographically restricted to a few countries, mostly in Africa and Middle East, but MWMV is now emerging in the Mediterranean Basin (Desbiez et al., 2017)

Other potyviruses infect cucurbits. They are not particularly related serologically or molecularly between each other and with ZYMV, WMV or the PRSV cluster (Table 1). Clover yellow vein virus and turnip mosaic have a broad host range and are present worldwide but are only minor viruses on cucurbits. The other viruses are more cucurbit-restricted and have a limited geographic distribution even if they can be locally important (Lecoq et al., 1998; Perotto et al., 2017).

\section{Poleroviruses}

Poleroviruses are persistently transmitted by aphids. They are phloem-restricted and are not mechanically transmissible. In cucurbits, poleroviruses usually induce yellowing symptoms on the older leaves that become thickened and brittle. They affect the yield of infected plants but have usually no impact on fruit quality. Poleroviruses have single-stranded positive-stranded RNA genomes of $5.6 \mathrm{~kb}$, encapsidated in icosahedral particles of circa $25 \mathrm{~nm}$ diameter. The first cucurbit polerovirus described in 1992 in France, cucurbit aphid-borne yellows virus (CABYV), was present there at least 10 years before but had long been unnoticed (Lecoq et al., 1992). Besides cucurbits, CABYV infects many weeds that are usually symptomless. CABYV is present worldwide except in some islands. Two main molecular groups have been observed, one containing Asian isolates, the other isolates from America, Africa and Europe (Kassem et al., 2013).

Besides CABYV, at least five poleroviruses inducing similar symptoms have later been described on cucurbits (Knierim et al., 2014) (Table 1). Recombinants between CABYV and melon aphid-borne yellows virus have been observed (Knierim et al., 2010). Except pepo aphid-borne yellows virus, all these viruses are present so far in Eastern Asia only (Table 1). No seed transmission was observed for cucurbit-infecting poleroviruses.

\section{WHITEFLY-TRANSMITTED VIRUSES: EMERGING VECTORS, EMERGING VIRUSES}


Whereas aphid-transmitted viruses remain important in temperate countries, whiteflytransmitted ones have emerged worldwide in the last decades. The greenhouse whitefly Trialeurodes vaporariorum and the tobacco whitefly Bemisia tabaci are the most important vectors. B. tabaci is now considered as a species complex including over 40 species (Elfekih et al., 2018). The MEAM1 and MED biotypes (formerly B and Q, respectively) have emerged throughout the world thanks to their high fitness and frequent resistance to insecticides. The most important viruses transmitted by whiteflies on cucurbits belong to the genera Begomovirus, Ipomovirus and Crinivirus.

\section{Begomoviruses}

Begomoviruses are single-stranded DNA viruses. Their genome consists of one or two circular DNAs (DNA-A and DNA-B) of $2.6 \mathrm{~kb}$ each, encapsidated in particles presenting a very typical double-icosahedral shape, giving its name to the Geminiviridae family (gemini $=$ twin). Begomoviruses are persistently transmitted by whiteflies from the Bemisia tabaci complex. Virus acquisition takes place within several hours of insect feeding, then the insects remain viruliferous for their whole life. There is generally no replication in the vector nor transovarian transmission to the offspring. Some begomoviruses are also transmitted by other whiteflies including $T$. vaporariorum (Sangeetha et al., 2018).

Begomoviruses belong to two molecular clades, « Old World» (OW) and « New World» (NW). The OW clade is considered as basal in begomovirus evolution. It contains both monopartite and bipartite viruses, whereas NW viruses are bipartite (Nawaz-ul-Rehman and Fauquet, 2009). Cucurbit-infecting begomoviruses are found both in the OW and NW clades and are mostly bipartite (Romay et al., 2014) (Table 1). Begomoviruses can be associated with satellite molecules that are ssDNA molecules of circa $1.3 \mathrm{~kb}$, dependent on their helper virus to complete their cycle. They do not encode any coat protein and are encapsidated in the capsid of their helper virus. Betasatellites usually increase the severity of viral infections and contribute to overcome resistance genes (Zhou, 2013). Alphasatellites, mostly associated with betasatellites, usually have no obvious effect on their helper virus (Zhou, 2013), but they can also contribute to reduce betasatellite accumulation and symptom severity (Idris et al., 2011). Satellites were thought to be associated with monopartite OW begomoviruses only, but atypical alphasatellites were found with some bipartite NW ones including melon chlorotic mosaic virus (MeCMV) (Romay et al., 2010). Beta- and alphasatellites are also associated with some OW bipartite begomoviruses, particularly tomato leaf curl New Delhi virus (ToLCNDV, see below)

Before 1998, only two begomoviruses were described on cucurbits: the OW watermelon chlorotic stunt virus (WmCSV) in the Red Sea region, and the NW squash leaf curl virus (SLCuV) in Central and Northern America (Lecoq and Desbiez, 2012), Since then, the emergence of B. tabaci MEAM1 and MED has prompted that of the viruses they transmit. Better knowledge of virus variability has also led to the characterization of new viruses and the distinction of members in species complexes, as for SLCuV and squash mild leaf curl virus that constitute different species. Asian squash-infecting begomoviruses are distinct from SLCuV and SqMLCV and constitute at least four species (Table 1) (https://talk.ictvonline.org/taxonomy/). Nowadays at least 18 begomovirus species are described on cucurbits, with contrasted geographic range and agronomic impact (Table 1). Limited long-distance exchanges have taken place: the NW virus SqLCV was introduced in the 2000s in Israel, Egypt and Jordan (Lecoq and Desbiez, 2012). The OW virus ToLCNDV was first described in India but is currently spreading in the Mediterranean Basin and Asia. ToLCNDV isolates from the Mediterrenean Basin are very homogeneous molecularly, suggesting a unique dissemination event (Zaidi et al., 2017; Juarez et al., 2019). The host range of ToLCNDV includes tomato as a major host, but also 43 other species including cucurbits (Zaidi et al., 2017). The emerging Mediterranean Basin isolates are highly adapted to cucurbits but do not perform well on tomato even if whitefly transmission between tomato and cucurbits is possible (Fortes et al., 2016). In its country of origin, ToLCNDV is frequently associated with satellites with a low specificity (it can replicate several different satellites). DNAA of ToLCNDV can also trans-replicate DNA-B of other begomoviruses, what may contribute to its 
great adaptability and epidemiological success. No satellite was associated with the emerging Mediterranean Basin isolates so far. ToLCNDV has not yet emerged in America and Eastern Asia.

\section{Ipomoviruses}

Ipomoviruses, like potyviruses, are members of the family Potyviridae. Contrary to potyviruses they are not aphid-borne but are transmitted by whiteflies in a semi-persistent way: acquisition and transmission happen in a few hours. The viruses do not multiply in the whiteflies and are not transmitted to the offspring. Three ipomoviruses infect cucurbits: cucumber vein yellowing virus (CVYV), squash vein yellowing virus (SqVYV) and coccinia mottle virus (CocMoV). They share a similar genomic organization, differing from that of potyviruses in the 5' part of the genome (Dombrovsky et al., 2014). Ipomoviruses induce vein yellowing and mosaic symptoms on cucurbit leaves. Synergism in co-infection with other viruses can result in enhanced symptoms and important losses (Gil-Salas et al., 2012). CVYV was first described in Israel in 1960, and has since been observed throughout the Middle East and Mediterranean Basin. It is now emerging in southern Europe in relation to high populations of B. tabaci MEAM1 and MED. Phylogenetic analyses suggested that CVYV originated in the Middle East (Velasco et al., 2016), but highly divergent and variable CVYV isolates were also observed in Sudan, indicating long-term presence of the virus in Sub-Saharan Africa. The strains now emerging in the Mediterranean Basin are more closely related to the Middle East isolates than to the Sudanese ones (Desbiez et al., 2019). CocMoV, has been described in Sudan on the wild perennial cucurbit Coccinia grandis. Although it readily infects cultivated cucurbits in laboratory conditions, it has never been observed on crops. This may be related to a low transmissibility by the local vectors or absence of crops in the vicinity of the infected coccinia. It is an example of a minor virus that might emerge if it is introduced in a favourable environment (Desbiez et al., 2016). SqVYV was first described in Florida (Adkins et al., 2007) and later in Puerto Rico and California. Its host range is mostly limited to cucurbits, the most severe symptoms being observed in squash and in watermelon, where it induces vine decline and fruit rot. It was found in 2014 in Israel (Reingold et al., 2016) and in Iran (Abkhoo, direct GenBank submission). The high molecular divergence between isolates from America, Israel and Iran suggest that the presence of the virus in these areas is not related to direct and recent genetic exchanges.

\section{Criniviruses}

Criniviruses are single-stranded bipartite RNA viruses that have thin filamentous flexuous particles. Four criniviruses infect cucurbits: beet pseudo-yellows virus (BPYV), lettuce infectious yellows virus (LIYV), cucurbit yellow stunting disorder virus (CYSDV) and cucurbit chlorotic yellows virus. (CCYV) The symptoms they induce on cucurbits are indistinguishable visually, and very similar to those of poleroviruses: interveinal yellowing of older leaves, sometimes spreading to almost all the plant for the most susceptible cultivars.

BPYV, the first whitefly-transmitted crinivirus described, has a wide host range including ornamentals, crops and weeds. Originally found in California, it is now present worldwide, probably in relation to frequent exchanges of susceptible hosts including vegetatively propagated ones. In temperate areas, BPYV is often found in greenhouses where the conditions are favourable for its vector T. vaporariorum.

LIYV was found in 1981 in the desert regions of California and Arizona (Wisler et al., 1998) where it caused important damages on cucurbits but also on lettuce and sugar beet. LIYV is well transmitted by the A biotype of $B$. tabaci but is very inefficiently transmitted by the MED and MEAM1 biotypes. When MEAM1 replaced the A biotype in the USA in the 1980s, LIYV completely disappeared but it was later replaced by viruses efficiently transmitted by MEAM1, particularly CYSDV (Wintermantel et al., 2017).

CYSDV and CCYV are transmitted by the same vector B. tabaci MEAM1 and MED and their dispersion patterns show some similarities. CYSDV was first described in the United Arab Emirates in 1982. It has spread to the whole Middle East and Mediterranean Basin in the 1980s1990s, and is also present in Sub-Saharan Africa (Mohammed et al., 2014). Its host range among crops is mostly restricted to cucurbits, but it infects numerous weeds that can constitute 
reservoirs (Orfanidou et al., 2019). It was detected in North America in 2000 and has now become an agronomic problem in that region, in relation to very high vector populations (Wintermantel et al., 2017). CCYV is also present in the Middle East and Sub-Saharan Africa and is now spreading in the Mediterranean Basin (Orfanidou et al., 2019) and North America (Wintermantel et al., 2019), but contrary to CYSDV it was first described in Japan (Okuda et al., 2010) and is present in China and Taiwan.

Molecular diversity within each crinivirus species is very limited, and makes it difficult to estimate genetic exchanges between distant areas (Orfanidou et al., 2019). For CYSDV, two clades have been described, "Eastern" (Arabia, Sudan, Iran) vs. "Western" (Mediterranean Basin). For CCYV, Asian and Mediterranean isolates were very similar, suggesting recent exchanges (Orfanidou et al., 2019).

\section{THRIPS-TRANSMITTED VIRUSES: GEOGRAPHICALLY RESTRICTED BUT LOCALLY IMPORTANT}

Six viruses in the genus Tospovirus, order bunyavirale, infect cucurbits. Tospoviruses are transmitted by thrips in a persistent multiplicative way. The viruses are acquired by larvae and transmitted by the adults, and they multiply in their vector. Indeed, many members of the bunyavirale are insect-infecting viruses and tospoviruses supposedly evolved from an insectinfecting ancestor (Marklewitz et al., 2015). Tospoviruses have a tripartite RNA genome, encapsidated in quasi-spherical enveloped particles 75 to $100 \mathrm{~nm}$ in diameter. Their symptoms on cucurbits are frequently very severe, including mosaics and dwarfing but also necrosis that can lead to plant death. The most common tospovirus wordwide is tomato spotted wilt virus (TSWV). It is a major pathogen on tomato and a wide range of crops and ornamentals, but on cucurbits it has only been observed occasionally in several regions of the world (Romay et al., 2014). The other cucurbit-infecting tospoviruses are geographically restricted and present a much narrower host range than TSWV but they can be locally important. Watermelon bud necrosis virus, watermelon silver mottle virus, and melon yellow spot virus (MYSV) are present in different countries from Asia (India, China, Thailand, Japan) whereas melon severe mosaic virus and zucchini lethal chlorosis virus were found in Latin and South America (Mexico, Brazil) (Table 1). No tospovirus has been observed inducing important epidemics so far in Europe, Africa and North America. However, the Asian MYSV was recently observed in Ecuador (Quito-Avila et al., 2014), indicating that the geographic structure of cucurbit tospoviruses is changing and long-distance spread can take place, probably through the trade of susceptible hosts or the accidental spread of viruliferous thrips. Since these viruses are very damaging and difficult to control, particular care should be taken to avoid their accidental long-distance dissemination.

\section{CONTACT, -SEED-AND SOIL-TRANSMITTED VIRUSES Tobamoviruses}

Tobamoviruses were the first plant viruses studied. Their high stability in and outside plants contributes to their efficient dissemination and the difficulty to control them. Tobamoviruses have a ssRNA genome of $\sim 6.5 \mathrm{~kb}$, encapsidated in rigid rod-shaped particles 300 $\mathrm{nm}$ long. They do not have a specific biotic vector, but they are easily transmitted by contact and remain infectious for a long time on surfaces, in plant debris or in water. They are also seedtransmitted (Dombrovsky and Smith, 2017). Contrary to other plant viruses, tobamoviruses seem to have undergone long-term co-evolution with their hosts as they constitute three clusters associated with asteroid, rosid or caryophyllid angiosperms. The most important tobamovirus on cucurbits is cucumber green mottle mosaic virus (CGMMV). CGMMV induces more or less severe leaf and fruit mottling, particularly in cucumber and watermelon (Dombrovsky and Smith, 2017). Since its first description in 1935 in England; its distribution to additional countries increased slowly between 1935 and 1985, faster between 1986 and 2006, and rapidly between 2007 and 2016 (Dombrovsky et al., 2017). It is now present on all continents except in South America. Seed transmission must have contributed to its rapid spread, as well as its ability to rapidly colonize weeds close to infected crops, making eradication efforts useless (Dombrovsky and Smith, 2017). Phylogenetic analyses indicated the presence of distinct CGMMV clades correlated with 
geographic origin of the isolates, showing a distinction between East Asia and European isolates (Dombrovsky and Smith, 2017), what does not appear consistent with a rapid worldwide dissemination through seed transmission. However phylogenetic signal is limited by the low genetic diversity of the virus.

At least five other tobamoviruses infect cucurbits (Table 1). They are mostly restricted to Eastern Asia so far (Table 1), even if their seed transmissibility makes them potential threats worldwide.

\section{Other seed-borne viruses}

Besides tobamoviruses, several viruses are transmitted through seed (Table 1), either via external contamination of the tegument or more rarely through infection of the embryo. Squash mosaic virus (genus Comovirus) is transmitted by several beetle species, mechanically by pruning operations, and by seeds, what is probably the means by which it has spread throughout the world (Lecoq et al., 1998). It can reach the embryo and multiply during germination, leading to rapid systemic infection of the plantlets (Lecoq and Katis, 2014). Melon rugose mosaic virus (genus Tymovirus) is seed transmitted in melon (Mahgoub et al., 1997); however it has not yet spread worldwide and is restricted so far to the Red Sea region.

Melon necrotic spot (MNSV, genus Carmovirus) is seed-transmitted in the presence of the soil fungus Olpidium bornovanus. The virus is carried in the seed, released in the soil during germination, and introduced in the plant by fungal zoospores. It is also transmitted directly from plant to plant by zoospores. $O$. bornovanus being a very resistant and ubiquitous fungus, vectorassisted seed transmission must have contributed to the worldwide spread of MNSV.

Traditional seed transmissibility tests include serological tests on seeds, what often greatly overestimate the real seed transmission, and observation of symptoms on plantlets after germination tests (Dombrovsky and Smith, 2017). However, in some cases plants infected from seed are asymptomatic and have very low virus titres that can be detected only by molecular methods (Simmons et al., 2013). Using molecular approaches, seed transmission was observed for viruses considered as non-seed-transmissible, including begomoviruses (Mabvakure et al., 2016; Sangeetha et al., 2018). The agronomic impact of cryptic infections after seed transmission is not well known, but since in some cases vector transmission to new plants has been demonstrated from asymptomatic plants infected from seeds, these plants can constitute primary inoculum to start epidemics. The importance of seed transmission for long-distance spread of plant viruses has probably long been underestimated, and particular care should be taken during seed trade.

\section{Soil-borne viruses}

Besides MNSV, some viruses are soil-transmitted, either by fungi or by nematodes. Several nepoviruses, transmitted by soil nematodes, infect cucurbits (Table 1). They generally have a broad host range outside cucurbits, including annual and perennial hosts. Each species is transmitted by a few specific nematode species, and some are also transmitted by seed. They are usually geographically restricted, but tobacco ringspot virus, endemic in cucurbits in America, has been reported on other crops in different areas where it probably spread through dissemination of infected plant material. Viruses transmitted by soil fungi include MNSV and other viruses in the same family Tombusviridae. They usually have a limited geographic distribution and their agronomic impact is low (Lecoq et al., 1998)

\section{MINOR AND PARTIALLY CHARACTERIZED VIRUSES}

Some viruses representing the unique cucurbit-infecting species in their genus have been known for long, but have never been observed outside the area where they were first described. It is the case for Ourmia melon virus, observed only in the North-West of Iran, the carlavirus melon yellowing-associated virus in Brazil, the torradovirus squash chlorotic leaf spot and the sobemovirus snake melon asteroid mosaic virus found only in Sudan (Table 1). Some of them may have a larger geographic range but may have been undetected because no accurate diagnostic was established. For highly damaging and/or widespread viruses, researches are usually undertaken 
to characterize their biological and molecular properties and develop serological or molecular diagnostic tools, but it is not always the case for minor viruses. On the other hand, the development of untargeted molecular diagnostic by high-throughput sequencing (HTS) has revealed viruses that were widespread but latent, both in crops and in wild plants (Prendeville et al., 2012). Endornaviruses, for instance, are only transmitted vertically and do not induce symptoms in their hosts (Fukuhara et al., 2006; Sabanadzovic et al., 2016). They represent some of the lately discovered commensal or even symbiotic viruses that have long been unnoticed because only viruses causing damages on crops were studied (Prendeville et al., 2012; Roossinck, 2012). The use of HTS for diagnostic is a very powerful tool for virus characterization, but it should not be disconnected from biology. Indeed, many recent descriptions of new viruses rely only on their sequence properties, without information on their symptomatology, host range or transmission properties, what makes it difficult to estimate the risks of dissemination and potential agronomic impact of these viruses.

\section{CONTROL OF VIRUSES}

Despite the high diversity of plant viruses and of their modes of dissemination, control measures against these pathogens are to a large extent common to many of them (Lecoq and Katis, 2014). There is no curative chemical treatment against plant viruses. Virus control relies mostly on cultural practices and the use of host genetic resistance when it is available.

Prophylaxis and good cultural practices involve limitation of virus sources and virus vectors in the crops and their vicinity. Weeding and the removal of volunteers before planting contribute to reduce the primary inoculum in crops. Overlapping crops should also be avoided, to limit the sources of infection to the young crops. Seeds can be produced in regions where seed-borne viruses are not prevalent, or mother plants may be grown under protected conditions. Serological or molecular testing of seed lots, and destruction of the positive ones, are important components of virus containment. For stable seed-borne viruses like CGMMV, seed treatment with chemicals or heat can reduce or abolish seed transmission. Long-distance movements of plant material should be limited to reduce the risks of virus spread.

In crops, plastic or unwoven covers can protect young plants from viruliferous insects, but the covers have to be removed to allow pollination. Plastic mulches contribute to the limitation of weeds and also have a repellent effect on aphids and whiteflies, at least until plant growth covers most of their surface. Disinfection of grafting and pruning tools with trisodium phosphate or skimmed milk is recommended (Coutts et al., 2013; Lecoq and Katis, 2014). Control of vectors in crops can be more easily achieved in greenhouse conditions, with the use of insect-proof netting, than in the field. Insecticide treatment or biological control of the vectors may contribute to reducing virus spread, particularly for persistently-transmitted viruses, but their efficiency against non-persistently transmitted viruses is limited or null.

Cross-protection, i.e. the use of a mild strain to protect plants against a severe strain of the same virus, has been used successfully against ZYMV. Attenuated strains have been obtained for several other viruses but have not been broadly used (Lecoq and Katis, 2014). One limitation of cross-protection is its high specificity (Lecoq and Katis, 2014).

When they are available, resistant cultivars constitute the easiest and most environmentally-friendly way to control viruses. Resistance traits have been searched in the biodiversity of cultivated species and their wild relatives since the beginning of the $20^{\text {th }}$ Century, both by private breeding companies and research institutes (Lecoq and Katis, 2014). Many commercial cultivars of cucurbits are resistant or tolerant to viruses. Most resistances used by breeders rely on one or a few major genes, as they were the most easily introgressed in agronomically interesting cultivars. Resistance factors can target any step of the virus cycle with very different mechanisms. Dominant resistance factors are involved in pathogen recognition of the virus, leading to a signalling pathway that results in induction of defence mechanisms. In the case of recessive resistance as well as non-host resistance, a plant factor required by the virus for its cycle is absent or modified so that the interaction with virus components cannot take place and the virus cannot complete its cycle (Lecoq and Katis, 2014). Pathogen-derived resistance has also 
been used commercially against ZYMV, PRSV and CMV in squash in the USA (Lecoq and Katis, 2014).

One limitation of the use of resistance genes is the availability of resistance factors against each virus. Introducing these factors in high-standard cultivars is costly and time-consuming and it is difficult to keep pace with the increasing number of viruses. Resistance genes corresponding to factors important for viral infectivity can constitute good candidates for broad-spectrum virus resistance. For instance, melon and cucumber plants mutated or silenced in a translation initiation factor required for potyvirus infection presented broad virus resistance (Chandrasekaran et al., 2016; Rodriguez-Hernandez et al., 2012). However, plant viruses have developed counter-defence mechanisms and can in some cases evolve rapidly by mutation or recombination to overcome host resistance (Desbiez et al., 2011b; Harrison, 2002). The selection of putatively durable resistance early in the selection scheme, the optimized deployment of resistances in agricultural landscapes and the selection of multigenic, partial and broad-spectrum resistances or tolerances could contribute to preserve the long-term efficiency of genetic virus control (Acosta-Leal et al., 2011).

\section{CONCLUSIONS}

The number of virus species described as infecting cucurbits is still rapidly increasing: About 20 species were described in 1980 (Lovisolo, 1980), 35 in 1998 (Lecoq et al., 1998), 59 in 2012 (Lecoq and Desbiez, 2012) and more than 90 in 2019 (Table 1). Among the "new" viruses described, some are endemic whereas others are present worldwide. Aphid-borne viruses still constitute major problems in temperate climates, whereas whitefly-transmitted ones are emerging in Mediterranean/tropical areas wherever the invasive MED and MEAM1 B. tabaci are present. The high increase in host connectivity due to global trade, as well as climatic changes involving changes in hosts and vectors, play important roles in the rapidly changing situation of plant viruses (Elena et al., 2014). Why some viruses emerge while others remain unimportant is partially understood. Intrinsic properties like seed transmissibility and a large host range ought to favour virus emergence, but it is not always the case (Table 1). Local ecological conditions, as well as the chance of introduction of minor viruses in the international trade, can influence the dissemination and potential emergence of plant viruses. Particular care should be taken when exchanging genetic material, and good practices involving seed disinfection and insect control should always be applied to limit the impact of viral diseases on cucurbits.

\section{ACKNOWLEDGEMENTS}

We thank Dr H. Lecoq for critical review of the manuscript

\section{Literature cited}

Acosta-Leal, R., Duffy, S., Xiong, Z., Hammond, R.W., and Elena, S.F. (2011). Advances in Plant Virus Evolution: Translating Evolutionary Insights into Better Disease Management. Phytopathol. 101, 1136-1148.

Adkins, S., Webb, S.E., Achor, D., Roberts, P.D., and Baker, C.A. (2007). Identification and characterization of a novel whitefly-transmitted member of the family Potyviridae isolated from cucurbits in Florida. Phytopathol. 97, 145-154.

Ben Tamarzizt, H., Montarry, J., Girardot, G., Fakhfakh, H., Tepfer, M., and Jacquemond, M. (2013). Cucumber mosaic virus populations in Tunisia peppers are mainly composed of virus reassortants with resistance-breaking properties. Plant Pathol. 62, 1415-1428.

Chandrasekaran, J., Brumin, M., Wolf, D., Leibman, D., Klap, C., Pearlsman, M., Sherman, A., Arazi, T., and Gal-On, A. (2016). Development of broad virus resistance in non-transgenic cucumber using CRISPR/Cas 9 technology. Mol. Plant Pathol. 17, 1140-1153.

Chen, K.C., Chiang, C.H., Raja, J.A., Liu, F.L., Tai, C.H., and Yeh, S.-D. (2008). A single amino acid of NIaPro of Papaya ringspot virus determines host specificity for infection of papaya. Mol. Plant Microbe Interact. 21, 1046-1057.

Coutts, B.A., Kehoe, M.A., and Jones, R.A.C. (2013). Zucchini yellow mosaic virus: Contact Transmission, Stability on Surfaces, and Inactivation with Disinfectants. Plant Dis. 97, 765-771.

Desbiez, C., Caciagli, P., Wipf-Scheibel, C., Millot, P., Ruiz Garcia, L., Marian, D., Dafalla, G., and Lecoq, H. (2019). Evidence for long-term prevalence of cucumber vein yellowing virus in Sudan and genetic variation of the virus in Sudan and the Mediterranean Basin. Plant Pathol., in press. https://doi.org/10.1111/ppa.13055.

Desbiez, C., Joannon, B., Wipf-Scheibel, C., Chandeysson, C., and Lecoq, H. (2009). Emergence of new strains of Watermelon mosaic virus in South-Eastern France: evidence for limited spread but rapid local population shift. Virus Res. 141, 201-208.

Desbiez, C., Joannon, B., Wipf-Scheibel, C., Chandeysson, C., and Lecoq, H. (2011). Recombination in natural populations of watermelon mosaic virus: new agronomic threat or damp squib? J. Gen. Virol. 92, 1939-1948. 
Desbiez, C., and Lecoq, H. (1997). Zucchini yellow mosaic virus. Plant Pathol. 46, 809-829.

Desbiez, C., and Lecoq, H. (2004). The nucleotide sequence of Watermelon mosaic virus (WMV, Potyvirus) reveals interspecific recombination between two related potyviruses in the 5' part of the genome. Arch. Virol 149, 1619-1632. Desbiez, C., Verdin, E., Tepfer, M., Wipf-Scheibel, C., Millot, P., Dafalla, G., and Lecoq, H. (2016). Characterization of a new cucurbit-infecting ipomovirus from Sudan. Arch. Virol 161, 2913-2915.

Desbiez, C., Wipf-Scheibel, C., Millot, P., Verdin, E., Dafalla, G., and Lecoq, H. (2017). New species in the papaya ringspot virus cluster: Insights into the evolution of the PRSV lineage. Virus Res. 241, 88-94.

Dombrovsky, A., Reingold, V., and Antignus, Y. (2014). Ipomovirus - an atypical genus in the family Potyviridae transmitted by whiteflies. Pest Management Sci. 70, 1553-1567.

Dombrovsky, A., and Smith, E. (2017). Seed Transmission of Tobamoviruses: Aspects of Global Disease Distribution. In Adv. Seed Biology, InTec, ed.

Dombrovsky, A., Tran-Nguyen, L.T.T., and Jones, R.A.C. (2017). Cucumber green mottle mosaic virus: Rapidly Increasing Global Distribution, Etiology, Epidemiology, and Management. Ann. Rev. Phytopathol. 55, 231-256.

Elena, S., Fraile, A., and Garcia-Arenal, F. (2014). Evolution and emergence of plant viruses. Adv. Virus Res. 88, 161-191. Elfekih, S., Tay, W.T., Gordon, K., Court, L.N., and De Barro, P.J. (2018). Standardized molecular diagnostic tool for the identification of cryptic species within the Bemisia tabaci complex. Pest Manag. Sci. 74, 170-173.

Fortes, I.M., Sánchez-Campos, S., Fiallo-Olivé, E., Díaz-Pendón, J.A., Navas-Castillo, J., and Moriones, E. (2016). A Novel Strain of Tomato Leaf Curl New Delhi Virus Has Spread to the Mediterranean Basin. Viruses 8, 307.

Fukuhara, T., Koga, R., Aoki, N., Yuki, C., Yamamoto, N., Oyama, N., Udagawa, T., Horiuchi, H., Miyazaki, S., Higashi, Y., et al. (2006). The wide distribution of endornaviruses, large double-stranded RNA replicons with plasmid-like properties. Arch. Virol 151, 995-1002.

Gil-Salas, F.M., Peters, J., Boonham, N., Cuadrado, I.M., and Janssen, D. (2012). Co-infection with Cucumber vein yellowing virus and Cucurbit yellow stunting disorder virus leading to synergism in cucumber. Plant Pathol. 61, 468-478.

Harrison, B.D. (2002). Virus variation in relation to resistance-breaking in plants. Euphytica 124, 181-192.

Idris, A.M., Shafiq Shahid, M., Briddon, R.W., Khan, A.J., Zhu, J.-K., and Brown, J.K. (2011). An unusual alphasatellite associated with monopartite begomoviruses attenuates symptoms and reduces betasatellite accumulation. J. Gen. Virol. 92, 706-717.

Jacquemond, M. (2012). Cucumber mosaic virus. Adv. Virus Res. 84, 440-504.

Juarez, M., Rabadan, M.P., Martinez, L.D., Tayahi, M., Grande-Perez, A., and Gomez, P. (2019). Natural Hosts and Genetic Diversity of the Emerging Tomato Leaf Curl New Delhi Virus in Spain. Front. Microb. 10, doi: 10.3389/fmicb.2019.00140 Kassem, M.A., Juarez, M., Gómez, P., Mengual, C.M., Sempere, R.N., Plaza, M., Elena, S.F., Moreno, A., Fereres, A., and Aranda, M.A. (2013). Genetic Diversity and Potential Vectors and Reservoirs of Cucurbit aphid-borne yellows virus in Southeastern Spain. Phytopathol. 103, 1188-1197.

Knierim, D., Deng, T.C., Tsai, W.S., Green, S.K., and Kenyon, L. (2010). Molecular identification of three distinct Polerovirus species and a recombinant Cucurbit aphid-borne yellows virus strain infecting cucurbit crops in Taiwan. Plant Pathol. 59, 991-1002.

Knierim, D., Tsai, W.S., Maiss, E., and Kenyon, L. (2014). Molecular diversity of poleroviruses infecting cucurbit crops in four countries reveals the presence of members of six distinct species. Arch. Virol 159, 1459-1465.

Lecoq, H., Bourdin, D., Wipf-Scheibel, C., Bon, M., Lot, H., Lemaire, O., and Herrbach, E. (1992). A new yellowing disease of cucurbits caused by a luteovirus, cucurbit aphid-borne yellows virus. Plant Pathol. 41, 749-761.

Lecoq, H., and Desbiez, C. (2012). Viruses of cucurbit crops in the Mediterranean region: an ever-changing picture. Adv. Virus Res. 84, 67-126.

Lecoq, H., Desbiez, C., Wipf-Scheibel, C., and Girard, M. (2003). Potential involvement of melon fruit in the long distance dissemination of cucurbit potyviruses. Plant Dis. 87, 955-959.

Lecoq, H., and Katis, N. (2014). Control of cucurbit viruses. Adv. Virus Res. 90, 255-296.

Lecoq, H., Wilser, G., and Pitrat, M. (1998). Cucurbit viruses: the classics and the emerging. Proc. Cucurbitaceae 98 ASHS \& US Dep. Agric.-ARS, Pacific Grove, CA, 126-142.

Lecoq, H., Wipf-Scheibel, C., Chandeysson, C., Le Van, A., Fabre, F., and Desbiez, C. (2009). Molecular epidemiology of Zucchini yellow mosaic virus in France: an historical overview. Virus Res. 141, 190-200.

Lecoq, H., Wipf-Scheibel, C., Nozeran, K., Millot, P., and Desbiez, C. (2014). Comparative molecular epidemiology provides new insights into Zucchini yellow mosaic virus occurrence in France. Virus Res. 186, 135-143.

Lovisolo, O. (1980). Virus and viroid diseases of cucurbits. Acta Hort. 88, 33-82

Mabvakure, B., Martin, D.P., Kraberger, S., Cloete, L., van Brunschot, S., Geering, A.D.W., Thomas, J.E., Bananej, K., Lett, J.M., Lefeuvre, P., et al. (2016). Ongoing geographical spread of Tomato yellow leaf curl virus. Virology 498, 257-264.

Mahgoub, H.A., Wipf-Scheibel, C., Delecolle, B., Pitrat, M., Dafalla, G., and Lecoq, H. (1997). Melon rugose mosaic virus: characterization of an isolate from Sudan and seed transmission in melon. Plant Dis. 81, 656-660.

Marklewitz, M., Zirkel, F., Kurth, A., Drosten, C., and Junglen, S. (2015). Evolutionary and phenotypic analysis of live virus isolates suggests arthropod origin of a pathogenic RNA virus family. Proc. Natl. Acad. Sci. USA 112, 7536-7541.

Mauck, K.E., De Moraes, C.M., and Mescher, M.C. (2010). Deceptive chemical signals induced by a plant virus attract insect vectors to inferior hosts. Proc. Natl Acad. Sci., USA 107, 3600-3605.

Mohammed, H.S., Zicca, S., Manglli, A., Mohamed, M.E., El Siddig, M.A., Tomassoli, L., and El Hussein, A.A. (2014). Identification and phylogenetic analysis of common pumpkin viruses in Sudan. J. Plant Pathol. 96, 77-84.

Nawaz-ul-Rehman, M.S., and Fauquet, C.M. (2009). Evolution of geminiviruses and their satellites. FEBS letters 583, 1825-1832.

Ng, J.C.K., and Perry, K.L. (2004). Transmission of plant viruses by aphid vectors. Mol. Plant Pathol.5, 505-511. 
Ohshima, K., Matsumoto, K., Yasaka, R., Nishiyama, M., Soejima, K., Korkmaz, S., Ho, S.Y.W., Gibbs, A.J., and Takeshita, M. (2016). Temporal analysis of reassortment and molecular evolution of Cucumber mosaic virus: Extra clues from its segmented genome. Virology 487, 188-197.

Okuda, M., Okazaki, S., Yamasaki, S., Okuda, S., and Sugiyama, M. (2010). Host Range and Complete Genome Sequence of Cucurbit chlorotic yellows virus, a New Member of the Genus Crinivirus Phytopathol. 100, 560-566.

Orfanidou, C.G., Papayiannis, L.C., Pappi, P.G., Katis, N.I., and Maliogka, V.I. (2019). Criniviruses associated with cucurbit yellows disease in Greece and Cyprus: an ever-changing scene. Plant Pathol. 68, 764-774.

Perotto, M.C., Pozzi, E.A., Celli, M.G., Luciani, C.E., Mitidieri, M.S., and Conci, V.C. (2017). Identification and characterization of a new potyvirus infecting cucurbits. Arch. Virol. 163, 719-724

Prendeville, H.R., Ye, X., Morris, J., and Pilson, D. (2012). Virus infections in wild plants are both frequent and often unapparent. Am. J. Bot. 99, 1-10.

Quito-Avila, D.F., Peralta, E.L., Martin, R.R., Ibarra, M.A., Alvarez, R.A., Mendoza, A., Insuasti, M., and Ochoa, J. (2014). Detection and occurrence of melon yellow spot virus in Ecuador: an emerging threat to cucurbit production in the region. Eur. J. Plant Pathol. 140, 193-197.

Reingold, V., Lachman, O., Sela, N., Luria, N., and Dombrovsky, A. (2016). Watermelon Fruit Rot Disease in Israel is Caused by a Distinct Squash vein yellowing virus (SqVYV) Strain. Plant Dis. 100, 1176-1183.

Rodriguez-Hernandez, A.M., Gonsalvez, B., Sempere, R.N., Burgos, L., Aranda, M.A., and Truniger, V. (2012). Melon RNA interference (RNAi) lines silenced for Cm-eIF4E show broad virus resistance. Mol. Plant Pathol.13, 755-763.

Romay, G., Chirinos, D., Geraud-Pouey, F., and Desbiez, C. (2010). Association of an atypical alphasatellite with a bipartite New World begomovirus. Arch. Virol 155, 1843-1847.

Romay, G., Lecoq, H., and Desbiez, C. (2014). Cucurbit crops and their viral diseases in Latin America and the Caribbean Islands: a review. J. Plant Pathol. 96, 227-242.

Roossinck, M.J. (2012). Plant virus metagenomics: biodiversity and ecology. Ann. Rev. Genet. 46, 349-359.

Sabanadzovic, S., Wintermantel, W.M., Valverde, R.A., McCreight, J.D., and Aboughanem-Sabanadzovic, N. (2016). Cucumis melo endornavirus: Genome organization, host range and co-divergence with the host. Virus Res. 214, 49-58.

Sangeetha, B., Malathi, V.G., Alice, D., Suganthy, M., and Renukadevi, P. (2018). A distinct seed-transmissible strain of tomato leaf curl New Delhi virus infecting Chayote in India. Virus Res. 258, 81-91.

Simmons, H.E., Dunham, J.P., Zinn, K.E., Munkvold, G.P., Holmes, E.C., and Stephenson, A.G. (2013). Zucchini yellow mosaic virus (ZYMV, Potyvirus): Vertical transmission, seed infection and cryptic infections. Virus Res. 176, 259-264.

Simmons, H.E., Holmes, E.C., Gildow, F.E., Bothe-Goralczyk, M.A., and Stephenson, A.G. (2011). Experimental Verification of Seed Transmission of Zucchini yellow mosaic virus. Plant Dis. 95, 751-754.

Velasco, L., Salem, N., Willemsen, A., Lapidot, M., Mansour, A.N., Rubio, L., and Galipienso, L. (2016). Genetic variation and evolutionary forces shaping Cucumber vein yellowing virus populations: risk of emergence of virulent isolates in Europe. Plant Pathol. 65, 847-856.

Wintermantel, W.M., Gilbertson, R.L., Natwick, E.T., and McCreight, J.D. (2017). Emergence and epidemiology of Cucurbit yellow stunting disorder virus in the American Desert Southwest, and development of host plant resistance in melon. Virus Res. 241, 213-219.

Wintermantel, W.M., Hladky, L.L.J., Fashing, P., Ando, K., and McCreight, J.D. (2019). First Report of Cucurbit Chlorotic Yellows Virus Infecting Melon in the New World. Plant Dis. 103, 778-778.

Wisler, G.C., Duffus, J.E., Liu, H.-Y., and Li, R.H. (1998). Ecology and epidemiology of whitefly-transmitted closteroviruses. Plant Dis. 82, 270-280.

Zaidi, S., Martin, D.P., Amin, I., Farooq, M., and Mansoor, S. (2017). Tomato leaf curl New Delhi virus: a widespread bipartite begomovirus in the territory of monopartite begomoviruses. Mol. Plant Pathol.18, 901-911.

Zhou, X. (2013). Advances in Understanding Begomovirus Satellites. Ann. Rev. Phytopathol. 51, 357-381. 
Table 1. Viruses infecting cucurbits and their biological properties. The most important or currently emerging viruses worldwide are indicated in bold. Viruses in italics are not yet acknowledged by the International Committee for the Taxonomy of Viruses (ICTV)

\begin{tabular}{|c|c|c|c|c|c|}
\hline \multirow[b]{2}{*}{ Genus and species } & \multirow[b]{2}{*}{ Means of spread } & \multirow{2}{*}{$\begin{array}{l}\text { First } \\
\text { description }\end{array}$} & \multirow{2}{*}{ Geographic distribution } & \multicolumn{2}{|c|}{ Host range } \\
\hline & & & & Cucurbits & $\begin{array}{l}\text { Outside } \\
\text { cucurbits }\end{array}$ \\
\hline • $\quad$ Begomovirus & & & & & \\
\hline Melon chlorotic mosaic virus (MeCMV) & Whitefly & 2004 & Venezuela & narrow & narrow \\
\hline Tomato leaf curl new Delhi virus (ToLCNDV) & Whitefly & 1948 & $\begin{array}{l}\text { Indian Peninsula, Mediterranean Basin, } \\
\text { Indonesia, Thailand }\end{array}$ & wide & wide \\
\hline Squash leaf curl virus (SLCuV) & Whitefly & 1981 & USA, Israel, Jordan, Egypt & wide & narrow \\
\hline Squash mild leaf curl virus (SMLCuV) & Whitefly & 1978 & USA, Jordan & narrow & narrow \\
\hline Watermelon chlorotic stunt virus (WmCSV) & Whitefly & 1994 & Iran, Yemen, Sudan, Israel & intermediate & narrow \\
\hline Cucurbit leaf crumple virus (CuLCrV) & Whitefly & 2000 & USA, Mexico & intermediate & narrow \\
\hline Melon chlorotic leaf curl virus (WCLCuV) & Whitefly & 2004 & Nicaragua, Costa Rica, Guatemala & wide & wide \\
\hline Telfairia golden mosaic virus (TelGMV) & Whitefly & 2016 & Cameroon & unknown & unknown \\
\hline Coccinia mosaic Tamil Nadu virus (CMTNDV) & Whitefly & 2016 & India & unknown & unknown \\
\hline Chayote yellow mosaic virus (ChaYMV) & Whitefly & 2016 & Nigeria, Benin, Togo & narrow & unknown \\
\hline Tomato leaf curl Palampur virus (ToLCPaV) & Whitefly & 2007 & India, Pakistan, Iran & wide & wide \\
\hline Tomato yellow leaf curl-Mild virus (TYLCV-Mld) & Whitefly & 1964 & Jordan, Latin America (on cucurbits) & narrow & intermediate \\
\hline Luffa yellow mosaic virus (LYMV) & Whitefly & 2003 & Vietnam & unknown & unknown \\
\hline Squash leaf curl China virus (SqLCCNV) & Whitefly & 1998 & Southern Asia, India & wide & unknown \\
\hline Squash leaf curl Philippines virus (SLCuPhV) & Whitefly & 2003 & Philippines & unknown & unknown \\
\hline Squash leaf curl Yunnan virus (SLCuYnV) & Whitefly & 2003 & China & unknown & unknown \\
\hline Pumpkin yellow mosaic virus (PuYMV) & Whitefly & 2001 & Malaysia & unknown & unknown \\
\hline $\begin{array}{l}\bullet \quad \text { Curtovirus } \\
\text { Beet curly top virus (BCTV) }\end{array}$ & Leafhopper & 1909 & Worldwide & wide & wide \\
\hline $\begin{array}{l}\bullet \quad \text { Clecrusatellite } \\
\text { Melon chlorotic mosaic alphasatellite (MeCMA) }\end{array}$ & whitefly & 2010 & Venezuela & narrow & narrow \\
\hline - Betasatellite & & & & & \\
\hline Momordica yellow mosaic betasatellite (MomYMB) & whitefly & 2016 & Benin & $\begin{array}{l}\text { (momordica, } \\
\text { chayote) }\end{array}$ & unknown \\
\hline $\begin{array}{l}\bullet \quad \text { Alphacryptovirus } \\
\text { Citrullus lanatus cryptic virus (CLCV) }\end{array}$ & Vertical & 2013 & Israel & unknown & unknown \\
\hline - Alphaendornavirus & & & & & \\
\hline Cucumis melo alphaendornavirus (CmEV) & Vertical t & 2016 & Worldwide & intermediate & unknown \\
\hline Lagenaria siceraria alphaendornavirus (LsEV) & Vertical & 2014 & China & & \\
\hline
\end{tabular}


- Nucleorhabdovirus

Eggplant mottled dwarf virus (EMDV)

- Tospovirus

Tomato spotted wilt virus (TSWV)

Zucchini lethal chlorosis virus (ZLCV)

Melon severe mosaic virus (MeCSV)

Watermelon silver mottle virus (WSMoV)

Melon yellow spot virus (MYSV)

Watermelon bud necrosis virus (WBNV)

- Tenuivirus

Melon chlorotic spot virus (MeCSV)

- Comovirus

Squash mosaic virus (SqMV)

- Fabavirus

Cucurbit mild mosaic virus (CuMMV)

- Nepovirus

Tobacco ringspot virus (TRSV)

Tomato ringspot virus (ToRSV)

Tobacco black ring virus (TBRV)

Artichoke yellow ringspot virus (AYRSV)

Melon mild mottle virus (MMMoV)

- Torradovirus

Squash chlorotic leaf spot virus (SqCLSV)

- Tymovirus

Melon rugose mosaic virus (MEMV)

Chayote mosaic virus (ChMV)

Wild cucumber mosaic virus (WCMV)

- Potexvirus

Lagenaria mild mosaic virus (LaMMoV)

- Carlavirus

Melon yellowing associated virus (MYaV)

Cucumber vein clearing virus (CuVCV)

- Potyvirus

Zucchini yellow mosaic virus (ZYMV)

Papaya ringspot virus (PRSV) leafhoppe

Thrips

Thrips

Thrips

Thrips

Thrips

Thrips

unknown

(planthopper?)

Beetle, seed

Aphid

Nematode, seed

nematode

nematode

nematode(?)

nematode(?)

Whitefly

Mechanical

Mechanical

Mechanical, beetle

Mechanical, seed

Whitefly

whitefly

Aphid

Aphid
1982

Mediterranean Basin

wide

Brazil

Mexico

China, Taiwan, Thailand

China, Japan, Thailand, India, Equador

India

France

\section{Worldwide}

Worldwide

Worldwide

Greece, Italy, Turkey

Japan

Sudan

Yemen, Sudan

Costa Rica

USA

2011 Myanmar, India

2005 Brazil

2011 Tanzania

1981 Worldwide

1949 Worldwide wide

narrow

unknown

unknown

wide

ntermediate

wide

wide

wide

intermediate

wide

wide

wide

wide

wide

wide

narrow

wide

wide

wide

wide

narrow

intermediate narrow

intermediate

wide

wide

narrow

unknown

(cucumber)

unknown

unknown

wide

wide intermediate narrow 


\section{Watermelon mosaic virus (WMV)}

Moroccan watermelon mosaic virus (MWMV)

Algerian watermelon mosaic virus (AWMV)

Zucchini yellow fleck virus (ZYFV)

Clover yellow vein virus (CIYVV)

Turnip mosaic virus (TuMV)

Melon vein-banding mosaic virus (MVBMV)

Telfairia mosaic virus (TelMV)

Watermelon leaf mottle virus (WLMV)

Zucchini tigré mosaic virus (ZTMV)

Zucchini shoestring virus (ZSTV)

Sudan watermelon mosaic virus (SuWMV)

Wild melon vein banding virus (WMVBV)

Cucurbit vein banding virus (CVBV)

- Ipomovirus

Cucumber vein yellowing virus (CVYV)

Squash vein yellowing virus (SqVYV)

Coccinia mottle virus (CocMoV)

- Polerovirus

Cucurbit aphid borne yellows virus (CABYV)

Melon aphid borne yellows virus (MABYV)

Suakwa aphid borne yellows virus (SABYV)

Luffa aphid borne yellows virus (LABYV)

Pepo aphid borne yellows virus (PABYV)

Cucumber aphid borne yellows Henan virus (CuABYV$\mathrm{Hn})$

- Tombusvirus

Cucumber necrosis virus (CNV)

Cucumber Bulgarian latent virus (CBLV)

- Aureusvirus

Cucumber leaf spot virus (CLSV)

- Carmovirus

Melon necrotic spot virus (MNSV)

Cucumber soil-borne virus (CuSBV)

- Necrovirus

Tobacco necrosis virus (TNV)
Aphid

Aphid

Aphid

Aphid

Aphid

Aphid

Aphid

Aphid

Aphid

Aphid

Aphid

Aphid

Aphid

Aphid

Whiteflies

Whiteflies

Whiteflies

Aphid

Aphid

Aphid

Aphid

Aphid

Aphid

Fungus,

Fungus

fungus,

mechanical

fungus, seed

fungus

Fungus
Worldwide

Africa, Mediterranean Basin

Algeria, Nigeria

France, Italy, Israel

Worldwide, occasional

Worldwide, occasional

China, Taiwan

Nigeria

\section{Florida}

America, Reunion, Myanmar, France

ndia, Pakistan, China

South Africa

Sudan

Sudan

Argentina

\section{Mediterranean Basin, Sudan}

USA, Israel

Sudan

\section{Worldwide}

2008 Taiwan, China

2009 Taiwan

2014 Thailand

2014 Africa, Greece

2014 China

1959

Canada, USA

Bulgaria

1982

Bulgaria, Greece, Spain France, Israel

1966

1983

Worldwide

Lebanon

wide

wide

wide

narrow

narrow

narrow

wide

wide

intermediate

wide

unknown

narrow

unknown

narrow

narrow

unknown

narrow

narrow

narrow

intermediate

unknown

unknown

unknown

unknown

unknown

wide

narrow

wide

narrow

wide

1935 France, Italy 
- Cucumovirus

- Ilarvirus

Tobacco streak virus (TSV)

Pollen, seed

Cucurbit yellow stunting disorder virus (CYSDV)

Whitefly

Beet pseudo-yellows virus (BPYV)

Lettuce infectious yellows virus (LIYV)

Whitefly

Whitefly

Cucurbit chlorotic yellows virus (CCYV)

Whitefly

- Tobamovirus

Cucumber green mottle mosaic virus (CGMMV)

Cucumber fruit mottle mosaic virus (CFMMV)

Kyuri green mottle mosaic virus (KGMMV)

Zucchini green mottle mosaic virus (ZGMMV)

Watermelon green mottle mosaic virus (WGMMV)

Mechanical, seed

Mechanical, seed

Mechanical, seed

Mechanical, seed

Cucumber mottle virus (CuMoV)

Mechanical, seed

Mechanical, seed

1996 Mediterranean Basin, Texas, Mexico

intermediate narrow

Mediter

1982 California wide wide

2010 China, Taiwan, Japan, Sudan, Iran, wide narrow

Greece, USA

1935 Worldwide

2001 Israel, Korea wide narrow

2000 Japan, Korea, Indonesia wide narrow

2000 Korea wide unknown

2019 Taiwan wide narrow

- Sobemovirus

Snake melon asteroid mosaic virus (SMAMV)

Japan

wide

narrow

- Ourmiavirus

Ourmia melon virus (OuMV)

Warnavirus

Watermelon virus A (WVA)

- Unknown

Watermelon crinkle-leaf associated virus 1 (WCLaV-1)

Watermelon crinkle-leaf associated virus 2 (WLCaV-2)

Beetle

Mechanical

2011

Sudan

narrow

narrow

1988 Iran

2017

China

unknown

unknown

unknown

2017

China

unknown

unknown

unknown

China

